\title{
Skrining Bakteri Dekomposer Sebagai Penghilang Bau Kotoran Ayam
}

\author{
Nika Ropiatningsuari a*, Suryo Wiyono ${ }^{\text {b }}$, Suryahadi ${ }^{\mathrm{c}}$ \\ ${ }^{a}$ Program Bioteknologi Tanah dan Lingkungan, Sekolah Pascasarjana, Institut Pertanian Bogor, Bogor, Jawa \\ Barat-Indonesia \\ ${ }^{b}$ Departemen Proteksi Tanaman, Fakultas Pertanian, Institut Pertanian Bogor, Bogor, Jawa Barat-Indonesia \\ ${ }^{c}$ Departemen Ilmu Nutrisi Pakan, Fakultas Peternakan, Institut Pertanian Bogor, Bogor, Jawa Barat-Indonesia \\ *Email: nikaropiatnings@gmail.com \\ Diterima (received) 13 Desember 2017; disetujui (accepted) 1 Februari 2018; tersedia secara online (available online) 1 Februari 2018
}

\begin{abstract}
The decomposition of chicken excreta produce odorous gases, that case environmental pollution. One of alternative technique to reduce the odorous gases is by applying specific bacteria. The aim of this study was to obtain bacterial isolates that capable of reducing $\mathrm{NH}_{3}$ and $\mathrm{H}_{2} \mathrm{~S}$ production and odors. Decomposer bacterial candidates were isolated from chicken manure, guano, and peat soil. Selection of isolates of oxidizing bacteria is carried out using selective media. All isolates that were found from chicken manure, guano, and peat soil tested for hypersensitive reaction on tobacco and hemolysis on blood agar. The isolated bacteria that showed negative HR and HL responses than used for a further experiment. Five isolates of bacteria which reduce odors based on organoleptic test were WiK 15 , TnK 7, WiGu 11, CGu 7 and $\mathrm{MaGa}_{5}$. $\mathrm{NH}_{3}$ and $\mathrm{H}_{2} \mathrm{~S}$ from decomposition chicken excreta were analyzed by spectrophotometric and colorimetric method. The average of total $\mathrm{NH}_{3}$ production from seven days observation showed ranged level from $1.09 \mathrm{ppm}$ to $1.77 \mathrm{ppm}$, while total $\mathrm{H}_{2} \mathrm{~S}$ gas production ranged from 15.05 to $16.57 \mathrm{ppm}$. Bacterial isolate CGU 7 showed make lowest total production of $\mathrm{NH}_{3}$.
\end{abstract}

Keywords:chicken excreta; odorous gases; oxidizing bacteria; reducing odors

\section{Pendahuluan}

Bau merupakan salah salah satu bentuk polusi udara. Polusi udara ini dapat berasal dari proses dekomposisi oleh bakteri. Umumnya bau berasal dari proses dekomposisi bahan yang mengandung ammonium, dimetilamin, trimetilamin, asam butirat, fenol, dan indol (Nowak et al., 2016). Sektor peternakan adalah salah satu sektor usaha yang potensial menjadi sumber pencemar udara. Dekomposisi kotoran ternak menghasilkan gas yang bersifat volatile dan kerap menjadi masalah bagi pekerja peternakan dan masyarakat sekitar peternakan. Di Indonesia peternakan ayam merupakan salah satu sektor peternakan yang kerap menganggu masyarakat sekitar peternakan karena berlokasi di daerah pemukiman.

Usaha perternakan ayam berkembang lebih cepat dibanding komoditas ternak lain. Tingginya kebutuhan daging atau telur ayam linear dengan biomassa kotoran yang dihasilkan serta gas dari proses dekomposisi. Secara umum jenis gas serta kadar yang dihasilkan tergantung pada proses dekomposisi, komposisi materi, dan waktu (Defoer dan Langenhove, 2002).

Proses dekomposisi litter ayam secara aerobik menghasilkan ammonia $\left(\mathrm{NH}_{3}\right)$, amina, indol $\left(\mathrm{C}_{8} \mathrm{H}_{7} \mathrm{~N}\right)$, skatol $\left(\mathrm{C}_{9} \mathrm{H}_{9} \mathrm{H}\right)$, asam lemak volatile, hidrogen sulfida $\left(\mathrm{H}_{2} \mathrm{~S}\right)$, dimetil disulfide $\left(\mathrm{C}_{2} \mathrm{H}_{6} \mathrm{~S}_{2}\right)$, dan dimetil trisulfit $\left(\mathrm{C}_{2} \mathrm{H}_{6} \mathrm{~S}\right.$ ) (Williams et al., 1999). Gas $\mathrm{NH}_{3}$ dan $\mathrm{H}_{2} \mathrm{~S}$ merupakan gas utama penyebab bau. Keberadaan gas $\mathrm{NH}_{3}$ dan $\mathrm{H}_{2} \mathrm{~S}$ di udara dapat mempengaruhi aktivitas masyarakat, kesehatan manusia dan produktivitas ternak. Patiyandela (2013), Paparan $\mathrm{H}_{2} \mathrm{~S}$ dengan konsentasi rendah dalam jangka waktu

doi: https://doi.org/10.24843/blje.2018.v18.i01.p03

(C) 2018 by the authors; Content from this work may be used under the terms of the Creative Commons Attribution 3.0 licence. Any further distribution of this work must maintain attribution to the author(s) and the title of the work, journal citation and DOI. Published under licence by Udayana University, Indonesia. 
yang lama dapat menyebabkan efek permanen seperti ganguan saluran pernapasan, sakit kepala, dan batuk kronis.

Mengingat besarnya dampak yang ditimbulkan dari paparan gas $\mathrm{NH}_{3}$ dan $\mathrm{H}_{2} \mathrm{~S}$ terhadap kesehatan manusia dan performa ternak (ayam), maka diperlukan upaya penanggulangan bau. Upaya penangulangan bau dapat dilakukan secara fisik dengan penaman pohon sekitar peternakan(Scanes et al. 2004), secara kimia dengan penambahan zeolit dan biologis dengan penggunaan bakteri. Bakteri memiliki kemampuan dalam mengabsorsi dan mengadsorbsi gas penyebab bau, serta mengabsorpsi komponen penyebab bau dengan cara oksidasi dan dekomposisi (Takagi et al. 1996). Menurut Lee et al. (2015) bakteri A. thiooxidans SOB5VT1 mampu menghilangkan sembilan senyawa penyebab bau yang mana diataranya adalah $\mathrm{NH}_{3}, \mathrm{H}_{2} \mathrm{~S}$, dan bahan organik yang volatil (VOCs).

Tujuan penelitian ini ialah untuk memperoleh bakteri yang mampu menekan bau Ekskreta ayam dan produksi gas $\mathrm{NH}_{3}$ dan $\mathrm{H}_{2} \mathrm{~S}$.

\section{Metode Penelitian}

Bakteri pengoksidasi $\mathrm{NH}_{3}$ dan $\mathrm{H}_{2} \mathrm{~S}$ dapat di temui pada lingkungan yang kaya kandungan $\mathrm{NH}_{3}$ dan sulfur. Bakteri pengoksidasi $\mathrm{NH}_{3}$ dan $\mathrm{H}_{2} \mathrm{~S}$ diisolasi dari kultur pengkayaan dengan media cair yakni Winogradsky's untuk bakteri pengoksidasi $\mathrm{NH}_{3}$, sedangkan media TSB (Tripic Soy Broth) dan media W untuk bakteri pengoksidasi $\mathrm{H}_{2} \mathrm{~S}$, diinkubasi dalam shaker incubator selama $7 \times 24$ jam pada suhu ruang. Metode isolasi yang akan dilakukan adalah metode sebar (spread plate) menggunakan media NA.

Isolat bakteri murni yang berasal dari media NA dilakukan skrining bakteri menggunakan media agar Winogradsky's (pengoksidasi $\mathrm{NH}_{3}$ ), media Centrimade, dan media W (pengoksidasi $\mathrm{H}_{2} \mathrm{~S}$ ). Hasil skrining bakteri pada media selektif selanjutnya di uji potensi patogenitas dengan metode hipersensitivitas (HR) pada tanaman tembakau dan uji hemolisis (HL) pada agar darah. Bakteri yang menunjukkan reaksi HR dan HL negatif selanjutnya dilakkukan uji organoleptik.

Uji organoleptik dilakukan menjelang tahap akhir sebelum pengukuran produksi $\mathrm{NH}_{3}$ dan $\mathrm{H}_{2} \mathrm{~S}$ dengan menambahkan inokulan bakteri. Ekskreta yang digunakan adalah eskreta basah ayam petelur yang ditampung selama \pm 72 jam menggunakan mulsa plastik. Sebanyak $100 \mathrm{~g}$ Ekskreta ayam yang homogen dimasukkan dalam erlenmayer dan diinokulasi satu jenis bakteri kemudian diinkubasi selama 14 hari. Masing-masing percobaan diseleksi berdasarkan kemampuan inokulat dalam mengurangi bau dari respondensi 11 orang dengan mengunakan metode one score one criteria system, dimana: $0=$ tidak bau; 1 $=$ agak bau; 2 = bau; 3 = sangat bau. Umur responden berkisar antara 22-26 tahun.

Pengukuran produksi $\mathrm{NH}_{3}$ dan $\mathrm{H}_{2} \mathrm{~S}$ dilakukan menggunakan $100 \mathrm{~g}$ Ekskreta ayam homogen dengan penambahan satu isolat bakteri terpilih dan diulang sebanyak tiga kali. Tiap perlakuan diinkubasi selama tujuh hari. Gas yang terbentuk dari tiap perlakuan dialirkan pada larutan penjerap dengan bantuan aerator. larutan $\mathrm{H}_{3} \mathrm{BO}_{3} 200 \mathrm{ml}$ digunakan untuk menjerap gas $\mathrm{NH}_{3}$ dan larutan $\mathrm{ZnC}_{4} \mathrm{H}_{6} \mathrm{O}_{4} \mathrm{H} 200 \mathrm{ml}$ digunakan untuk menjerap untuk gas $\mathrm{H}_{2} \mathrm{~S}$. Metode kolorimetri digunakan untuk analisis gas $\mathrm{NH}_{3}$ dan metode spektrofotometer untuk gas $\mathrm{H}_{2} \mathrm{~S}$. Hasil penelitian dianalisis menggunakan Analisis of Variance (Anova) dengan Software SAS (Statistical analysis system) dan data kualitatif disajikan dalam bentuk tabel dan gambar. Jika terdapat pengaruh signifikan maka dilakukan uji lanjut Duncan Multiple Range Test (DMRT) $1 \%$.

\section{Hasil dan Pembahasan}

\subsection{Hasil Penelitian}

\subsubsection{Isolasi dan Skrining Bakteri Pengoksidasi $\mathrm{NH}_{3}$ dan $\mathrm{H}_{2} \mathrm{~S}$}

Isolasi bakteri dari kotoran ayam, guano, dan tanah gambut dengan media pengkayaan spesifik Winogradsk'y, TSB, dan media W cair ditumbuhkan pada media NA dan diperoleh 184 isolat. Isolat bakteri yang diperoleh selanjutnya tumbuhkan pada media agar spesifik Winogradsk'y, Martin agar, Centrimade, dan ThioBacillus untuk melihat kemampuan tumbuh bakteri. Bakteri yang mampu tumbuh 
pada media spesifik diduga sebagai bakteri pengoksidasi. Hasil proses skrining diperoleh 164 bakteri. Masing-masing isolat yang diperoleh diuji pada tahap selanjutnya.

\subsubsection{Uji Hipersensitivitas dan Uji Hemolisis}

Hasil proses isolasi dan skrining bakteri pada media selektif diperoleh 164 bakteri. Isolat bakteri yang diperoleh diuji potensi fitopatologi dan patogen mamalia (Tabel 1).

Tabel 1. Uji potensi fitopatogenitas dan potensi patogen mamalia

\begin{tabular}{cccccc}
\hline Sumber & Jumlah isolat & Jumlah HR (+) & $\begin{array}{c}\text { \% HR } \\
(+)\end{array}$ & Jumlah HL (+) & \% HL (+) \\
\cline { 2 - 6 } & & & 8.33 & 34 & 56.6 \\
Kotoran ayam & 60 & 5 & 20.3 & 25 & 39.1 \\
Guano & 64 & 13 & 0.75 & 28 & 70 \\
Gambut & 40 & 3 & & 87 & \\
\hline Total & 164 & 21 & & & \\
\hline
\end{tabular}

\subsubsection{Uji Organoleptik}

Uji organoleptik menggunakan metode one score one test untuk mengetahui skala bau. Nilai ratarata hasil respondensi dapat dillihat pada Gambar 1. Sedangkan pada Gambar 2 menujukkan perbedaan permukaan Ekskreta uji setelah diberi perlakuan.

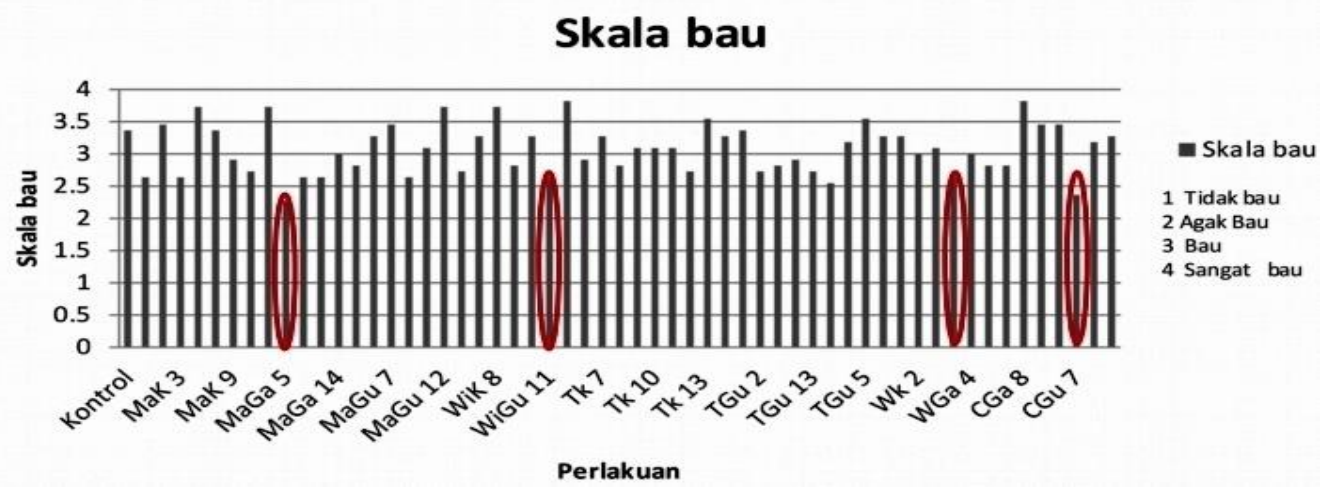

Gambar 1. Diagram nilai skala bau uji organoleptik pada Ekskreta ayam

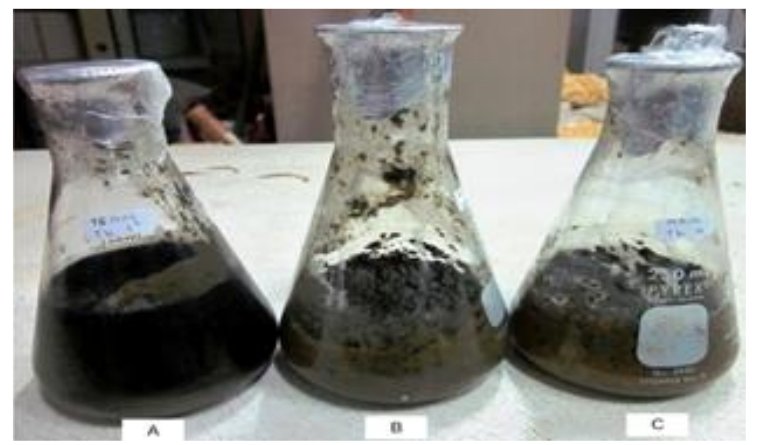

Gambar 2. Tampilan permukaan Ekskreta ayam. (a) seluruh permukaan Ekskreta berwarna hitam, (b) bagian atas permukaan Ekskreta berwarna hitam, dan (c) seluruh permukaan berwarna coklat. 
3.1.4. Pengukuran Produksi Total Ammoniak $\left(\mathrm{NH}_{3}\right)$ dan Hidrogen Sulfida $\left(\mathrm{H}_{2} \mathrm{~S}\right)$

Pengaruh pemberian isolat bakteri terpilih daalam menekan produksi gas $\mathrm{NH}_{3}$ dan $\mathrm{H}_{2} \mathrm{~S}$ pada $100 \mathrm{~g}$ Ekskreta ayam dapat dilihat dari total produksi gas selama tujuh hari. Total produksi gas $\mathrm{NH}_{3}$ dan $\mathrm{H}_{2} \mathrm{~S}$ ditunjukkan pada Gambar 3.
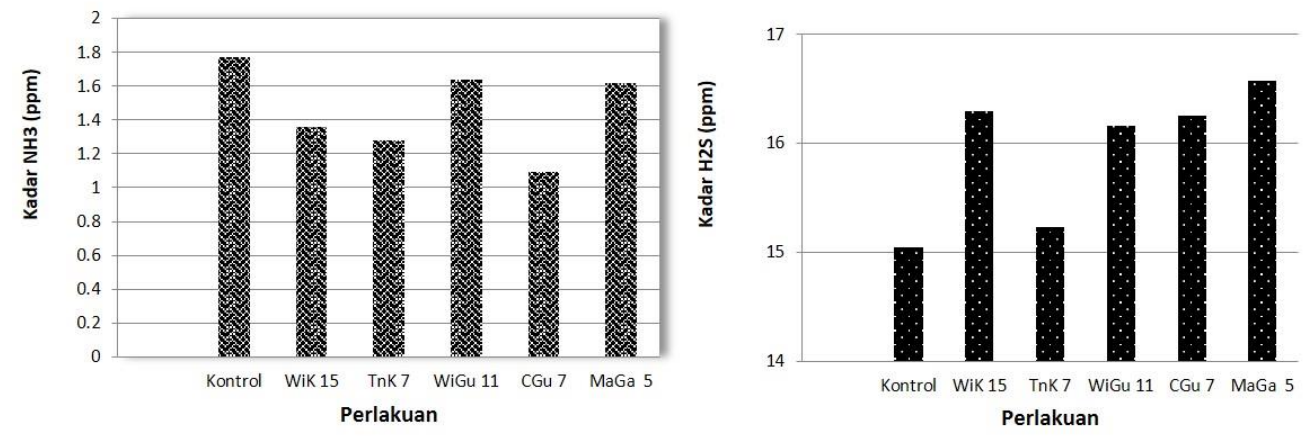

Gambar 3. Total produksi gas $\mathrm{NH}_{3}$ dan $\mathrm{H}_{2} \mathrm{~S}$ pada Ekskreta ayam

\subsubsection{Pola produksi harian $\mathrm{NH}_{3}$ dan $\mathrm{H}_{2} \mathrm{~S}$}

Perbedaan kemampuan oksidasi dipengaruhi oleh jenis isolat bakteri. Perbedaan tersebut ditujukkan pada pola produksi gas $\mathrm{NH}_{3}$ (Tabel 2) dan $\mathrm{H}_{2} \mathrm{~S}$ (Tabel 3) tiap perlakuan perhari.

Tabel 2. Produksi $\mathrm{NH}_{3}$ perhari Ekskreta ayam pada berbagai perlakuan

\begin{tabular}{ccccccccc}
\hline Perlakuan & \multicolumn{7}{c}{ Produksi gas NH3 hari ke- (ppm) } & $\begin{array}{c}\text { Total } \\
\text { produksi } \\
\text { nyyyyyyyy}\end{array}$ \\
\cline { 2 - 9 } & 1 & 2 & 3 & 4 & 5 & 6 & 7 & $1.76 \mathrm{a}$ \\
\hline Kontrol & $0.32 \mathrm{a}$ & $0.10 \mathrm{a}$ & $0.14 \mathrm{a}$ & $0.52 \mathrm{a}$ & $0.4 \mathrm{ab}$ & $0.14 \mathrm{a}$ & $0.15 \mathrm{a}$ & $1.36 \mathrm{a}$ \\
WiK 15 & $0.23 \mathrm{a}$ & $0.19 \mathrm{a}$ & $0.25 \mathrm{a}$ & $0.22 \mathrm{~b}$ & $0.12 \mathrm{c}$ & $0.24 \mathrm{a}$ & $0.12 \mathrm{a}$ & $1.28 \mathrm{a}$ \\
TnK 7 & $0.33 \mathrm{a}$ & $0.17 \mathrm{a}$ & $0.13 \mathrm{a}$ & $0.25 \mathrm{c}$ & $0.26 \mathrm{abc}$ & $0.09 \mathrm{a}$ & $0.05 \mathrm{a}$ & $1.64 \mathrm{a}$ \\
WiGu 11 & $0.29 \mathrm{a}$ & $0.18 \mathrm{a}$ & $0.51 \mathrm{a}$ & $0.23 \mathrm{~b}$ & $0.19 \mathrm{bc}$ & $0.19 \mathrm{a}$ & $0.05 \mathrm{a}$ & $1.09 \mathrm{a}$ \\
CGu 7 & $0.16 \mathrm{a}$ & $0.23 \mathrm{a}$ & $0.27 \mathrm{a}$ & $0.15 \mathrm{bc}$ & $0.07 \mathrm{c}$ & $0.15 \mathrm{a}$ & $0.07 \mathrm{a}$ & $1.62 \mathrm{a}$ \\
MaGa 5 & $0.30 \mathrm{a}$ & $0.41 \mathrm{a}$ & $0.08 \mathrm{a}$ & $0.10 \mathrm{bc}$ & $0.44 \mathrm{a}$ & $0.19 \mathrm{a}$ & $0.11 \mathrm{a}$ & \\
\hline
\end{tabular}

Keterangan: Pengolahan data, setelah data ditransformasi log 10 (x) produksi $\mathrm{NH}_{3}(\mathrm{ppm})$

Tabel 3. Pola produksi $\mathrm{H}_{2} \mathrm{~S}$ perhari Ekskreta ayam pada berbagai perlakuan

\begin{tabular}{ccccccccc}
\hline Perlakuan & \multicolumn{7}{c}{ Produksi gas H2S hari ke- $(\mathbf{p p m})$} & $\begin{array}{c}\text { Total } \\
\text { produksi } \\
\end{array}$ \\
\cline { 2 - 8 } & 1 & 2 & 3 & 4 & 5 & 6 & 7 & $15.0 \mathrm{a}$ \\
\hline Kontrol & $1.62 \mathrm{~b}$ & $1.92 \mathrm{~b}$ & $2.43 \mathrm{ab}$ & $1.94 \mathrm{~b}$ & $2.22 \mathrm{c}$ & $2.34 \mathrm{a}$ & $2.58 \mathrm{a}$ & $16.29 \mathrm{a}$ \\
WiK 15 & $2.22 \mathrm{a}$ & $2.27 \mathrm{ab}$ & $2.52 \mathrm{a}$ & $2.35 \mathrm{a}$ & $2.48 \mathrm{a}$ & $2.28 \mathrm{a}$ & $2.17 \mathrm{a}$ & $15.23 \mathrm{a}$ \\
TnK 7 & $2.12 \mathrm{a}$ & $1.92 \mathrm{~b}$ & $2.32 \mathrm{~b}$ & $2.00 \mathrm{~b}$ & $2.19 \mathrm{c}$ & $2.45 \mathrm{a}$ & $2.23 \mathrm{a}$ & $15.16 \mathrm{a}$ \\
WiGu 11 & $2.31 \mathrm{a}$ & $2.17 \mathrm{ab}$ & $2.51 \mathrm{ab}$ & $2.22 \mathrm{a}$ & $2.51 \mathrm{a}$ & $2.23 \mathrm{a}$ & $2.21 \mathrm{a}$ & $16.25 \mathrm{a}$ \\
CGu 7 & $2.39 \mathrm{a}$ & $2.34 \mathrm{a}$ & $2.49 \mathrm{ab}$ & $2.22 \mathrm{a}$ & $2.42 \mathrm{ab}$ & $2.22 \mathrm{a}$ & $2.17 \mathrm{a}$ & 16.25 \\
MaGa 5 & $2.34 \mathrm{a}$ & $2.63 \mathrm{a}$ & $2.41 \mathrm{ab}$ & $2.00 \mathrm{~b}$ & $2.29 \mathrm{bc}$ & $2.4 \mathrm{a}$ & $2.5 \mathrm{a}$ & $16.57 \mathrm{a}$ \\
\hline
\end{tabular}

Keterangan: Pengolahan data, setelah data ditransformasi akar kuadrat 
3.1.6. Karakterisasi morfologi dan biokimia bakteri uji

Morfologi dan hasil uji biokimia bakteri uji ditunjukkan pada Tabel 4.

Tabel 4. Karakterisasi morfologi dan biokimia bakteri uji

\begin{tabular}{|c|c|c|c|c|c|}
\hline \multirow[t]{2}{*}{ Karakteristik } & \multicolumn{5}{|c|}{ Kode Isolat } \\
\hline & WiK 15 & TK 7 & WiGu 11 & $\mathrm{CGu} 7$ & MaGa 5 \\
\hline Asal isolat & Kotoran ayam & Kotoran ayam & Guano & Guano & Gambut \\
\hline Morfologi & & & & & \\
\hline Warna & Putih & Putih & Putih & Putih & Putih \\
\hline Bentuk & Bulat & Bulat & Bulat & Bulat & Bulat \\
\hline Elevasai & Cembung & Cembung & Cembung & Cembung & Cembung \\
\hline Margin & Rata & Rata & Rata & Rata & Rata \\
\hline Permukaan & Halus & Halus & Halus & Halus & Halus \\
\hline & mengkilap & mengkilap & mengkilap & mengkilap & mengkilap \\
\hline $\begin{array}{c}\text { Bentuk sel } \\
\text { Biokimia }\end{array}$ & Basil & Basil & Basil & Coccus & Basil \\
\hline Pigmen & - & - & - & - & - \\
\hline Gram & - & - & - & - & - \\
\hline Motilitas & + & + & + & + & + \\
\hline Oksidase & + & - & + & + & + \\
\hline Katalase & + & + & + & + & + \\
\hline
\end{tabular}

\subsection{Pembahasan}

\subsubsection{Isolasi dan Skrining Bakteri Pengoksidasi $\mathrm{NH}_{3}$ dan $\mathrm{H}_{2} \mathrm{~S}$}

Isolasi bakteri dari kotoran ayam, guano, dan tanah gambut dengan media pengkayaan spesifik Winogradsk'y, TSB, dan media W cair ditumbuhkan pada media NA dan diperoleh 184 isolat. Isolat bakteri yang diperoleh selanjutnya tumbuhkan pada media agar spesifik Winogradsk'y, Martin agar, Centrimade, dan ThioBacillus untuk melihat kemampuan tumbuh bakteri. Bakteri yang mampu tumbuh pada media spesifik diduga sebagai bakteri pengoksidasi.

\subsubsection{Uji Hipersensitivitas dan Uji Hemolisis}

Isolat bakteri yang diperoleh pada tahap skrining menggunakan media selektif agar, selanjutnya dianalisis untuk mengetahui potensi fitopatogenitas dan pada mamalia Berdasarkan Tabel 1 diketahui bahwa isolat bakteri dari guano memiliki persentase potensi fitopatogen tertinggi, sekitar $20.3 \%$. Persentase potensi fitopatogenitas tersebut dapat menjadi bahan pertimbangan pengunaan guano sebagai sumber pupuk P organik, Isolat bakteri potensial non-fitopatogen selanjutnya diuji kemampuan hemolisis pada agar darah dan diinkubasi selama 48 jam. Hasil uji hemolisis pada agar darah menunjukkan bahwa bakteri asal tanah gambut memiliki persentase potensial patogen pada mamalia sebesar $70 \%$. Hasil uji potensi fitopatogenitas dan patogenitas mamalia menunjukkan bahwa tidak semua isolat bakteri aman digunakan.

\subsubsection{Uji Organoleptik}

Hasil respondensi uji organoleptik dari 56 perlakuan bakteri terhadap aroma Ekskreta menujukkan bahwa nilai terendah adalah pada penambahan isolat bakteri WiGu 11, WiK 15, CGu 7 dan MaGa 5.Data organoleptik digunakan sebagai salah satu metode uji kemampuan bakteri dalam menekan bau pada Ekskreta ayam. Perbedaan tingkat aroma yang dihasilkan menunjukkan pengaruh berbagai isolat uji. Kisaran nilai rata-rata bau terendah dari keempat isolat tersebut adalah 2.3 - 2.6. Pada uji tingkat bau, 
diketahui bahwa isolat TnK 7 menunjukkan perbedaan yang signifikan pada tampilan permukaan Ekskreta ayam. Perbedaan tampilan tersebut menjadi dasar pemilihan isolat TnK 7 sebagai isolat uji pada tahap selanjutnya. Isolat terpilih selanjutnya diaplikasikan pada Ekskreta ayam untuk mengetahui kemampuan dalam menekan produksi gas penyebab bau. Rahman dan Borhan (2012) menyebutkan, bahan penyebab bau dapat diklasifikasikan menjadi lima kelas yakni; senyawa nitrogen (gas amoniak), alkohol, sulfur ( $\mathrm{H}_{2} \mathrm{~S}$ dan markaptan) asam lemak volatile (VFAs), dan bahan aromatik (indol, fenol). Ekskreta ayam mengandung semua komponen bahan penyebab abu sehingga gas yang dihasilkan bersifat komplek.

\subsubsection{Produksi total gas $\mathrm{NH}_{3}$ dan $\mathrm{H}_{2} \mathrm{~S}$}

Isolat bakteri asal kotoran ayam (WiK 15 dan TnK 7), guano (WiGu 11 dan CGu 7) serta gambut (MaGa 5) digunakan dalam uji lanjut untuk mengukur produksi $\mathrm{NH}_{3}$ dan $\mathrm{H}_{2} \mathrm{~S}$ pada $100 \mathrm{~g}$ Ekskreta ayam selama tujuh hari. Produksi total gas $\mathrm{NH}_{3}$ dari masing-masing perlakuan berkisar antara $1.09-1.76 \mathrm{ppm}$, sedangkan produksi total gas $\mathrm{H}_{2} \mathrm{~S}$ berkisar antara 15.05 - $16.57 \mathrm{ppm}$ (Gambar 3). Gambar 3 menunjukkan produksi total gas $\mathrm{NH}_{3}$ dan $\mathrm{H}_{2} \mathrm{~S}$ tidak berbeda nyata. Produksi $\mathrm{NH}_{3}$ terendah dari penambahan isolat bakteri pada Ekskreta kotoran ayam sebesar 38.42\% oleh isolat CGu 7 yakni 1.09 ppm. Persentase penurunan produksi $\mathrm{NH}_{3}$ dengan penambahan isolat CGu 7 lebih tinggi dibandingkan penelitian Muchayani (2013) dengan pemberian probiotik padat kompleks (LactoBacillus, Bifidobacterium, Streptococcus, dan Bacillus) pada pakan sapi potong sebesar $30.06 \%$ feses basah dan $37.97 \%$ feses kering.

Pada penambahan isolat bakteri pada penelitian ini terhadap produksi gas $\mathrm{H}_{2} \mathrm{~S}$ menujukkan peningkatan produksi gas $\mathrm{H}_{2} \mathrm{~S}$. Kenaikan produksi gas $\mathrm{H}_{2} \mathrm{~S}$ tertinggi sebesar $10.10 \%$ ditujukkan pada penambahan isolat MaGa5 yakni $16.57 \mathrm{ppm}$. nilai tersebut berbanding terbalik dengan hasil uji kualitatif (organoleptik). Perbedaan hasil yang diperoleh dari hasil uji organoleptik dapat disebabkan karena ketidakmampuan manusia dalam membedakan bau dari suatu gas tertentu, keberadaan senyawa volatile lain, faktor kebiasaan responden, serta sensitivitas responden (Kerr, 1978). Menurut Prasetyanto (2011), batas konsentrasi $\mathrm{H}_{2} \mathrm{~S}$ di udara yang dapat menyebabkan bau busuk sebesar $0.47 \mathrm{ppm}$, sedangkan menurut Palgunadi et al. (1999), gas $\mathrm{H}_{2} \mathrm{~S}$ terdeteksi pada konsentrasi $0.1 \mathrm{ppm}$, dan menurut Syafrizal dan Dianursanti (2011), $\mathrm{H}_{2} \mathrm{~S}$ dapat dideteksi dalam konsentrasi $0.002 \mathrm{ppm}$. Sensitivitas merupakan salah satu faktor kelemahan dari penggunaan uji kualitatif, oleh karena itu uji kuantitatif diperlukan. Pemberian isolat bakteri dalam menekan produksi gas $\mathrm{NH}_{3}$ dan $\mathrm{H}_{2} \mathrm{~S}$ lebih jelas dapat dilihat dari pola produksi gas harian.

\subsubsection{Pola Produksi gas $\mathrm{NH}_{3}$ dan $\mathrm{H}_{2} \mathrm{~S}$ harian}

Berdasarkan Tabel 2 diketahui produksi gas harian yang cenderung fluktuatif serta produksi $\mathrm{NH}_{3}$ total selama tujuh hari tidak berbeda nyata. Namun demikian, pada hari keempat setelah aplikasi seluruh isolat berpengaruh nyata, dan pada hari kelima isolat yang berpengaruh nyata ditujukkan oleh WiK 15 , WiGu 11, dan CGu 7. Pada hari ke tujuh semua perlakuan menunjukkan penurunan produksi gas $\mathrm{NH}_{3}$. Penurunan produksi tersebut diduga disebabkan oleh kemampuan oksidasi bakteri serta penurunan kandungan nutrisi, air (kelembaban) selama waktu inkubasi. Perbedaan waktu produksi $\mathrm{NH}_{3}$ yang diduga dipengaruhi oleh jenis isolat bakteri berbeda, sesuai dengan percobaan Chesson (1994), dimana laju pertumbuhan serta kemampuan kompetisi yang berbeda antar spesies yang berbeda.

Namun meski analisis sidik ragam produksi $\mathrm{NH}_{3}$ total tidak berpengaruh nyata, kisaran total produksi $\mathrm{NH}_{3}$ tiap perlakuan tergolong rendah yakni $1.09-1.76 \mathrm{ppm}$. Menurut Prasetyanto (2011) kadar terendah untuk menimbulkan bau adalah $5 \mathrm{ppm}$, dengan demikian $\mathrm{NH}_{3}$ bukan merupakan gas yang berpengaruh terhadap bau yang di timbulkan pada uji organopetik.

Tabel 3 menunjukkan pola produksi gas $\mathrm{H}_{2} \mathrm{~S}$ yang lebih fluktuatif dibanding pola produksi gas $\mathrm{NH}_{3}$. Rata-rata produksi gas tiap perlakuan berkisar antara $2.15-2.36 \mathrm{ppm}$. nilai tersebut terbilang cukup tinggi dalam menimbulkan bau. Prasetyanto (2011) melaporkan, bahwa batas konsentrasi $\mathrm{H}_{2} \mathrm{~S}$ di udara yang dapat menyebabkan bau busuk adalah $0.47 \mathrm{ppm}$. Berdasarkan hasil pengukuran produksi gas diketahui 
bahwa $\mathrm{H}_{2} \mathrm{~S}$ merupakan salah satu gas yang terdeteksi pada uji organoleptik karena kadar $\mathrm{NH}_{3}$ yang terukur berada dibawah kadar minimal. Produksi gas $\mathrm{H}_{2} \mathrm{~S}$ pada hari pertama dari Ekskreta ayam dengan penambahan isolat lebih tinggi dibanding kontrol. Penurunan produksi tiap isolat hanya terjadi pada hari ketujuh, namun tidak berpengaruh nyata, sehingga total produksi gas $\mathrm{H}_{2} \mathrm{~S}$ dengan penambahan isolat bakteri justeru lebih tinggi dibanding kontrol.

Berbagai upaya dalam menghilangkan bau telah sejak lama dilakukan namun tidak semua memperoleh hasil yang posistif. Beberapa diantaranya menunjukkan penurunan yang tidak berbeda nyata bahkan kenaikan produksi gas $\mathrm{H}_{2} \mathrm{~S}$. Rahman et al. (2011) dalam upaya mengurangi gas $\mathrm{NH}_{3}$ dan $\mathrm{H}_{2} \mathrm{~S}$ dengan penambahan bakteri (Digest3+3○) hanya mampu menghilangkan $\mathrm{H}_{2} \mathrm{~S}$ sebesaar $6.66 \%$. Hidayatun (2007) mengaplikasikan tepung kemangi (Ocimum basilicum) dalam pakan komersil ayam broiler sebagai upaya penanggulangan bau dengan konsentrasi pemberian 1\%, 2\%, dan 3\%. Dalam penelitian tersebut penurunan produksi $\mathrm{H}_{2} \mathrm{~S}$ hanya terjadi pada perlakuan $1 \%$ dengan penurunan sebesar $1.59 \%$ dan kenaikan produksi pada perlakuan $3 \%$ sebesar $8.73 \%$. namun tidak sedikit diantaranya yang menujukkan hasil yang berbeda nyata. Metode biofilter merupakan salah satu metode mengurangi bau dengan tingkat keberhasilan tertinggi. Lee et al. (2015) mampu menghilangkan gas $\mathrm{H}_{2} \mathrm{~S}$ sebesar $99.88 \%$ dengan menggunakan Acidithiobacillus thiooxidans SOB5VT1. Sedangkan Chung et al. (1996) menggunakan Pseudomonas putida CH11 menurunkan kadar $\mathrm{H}_{2} \mathrm{~S}$ hingga 93.33\%, dan Chung et al. (2001) penggunaan bakteri Pseudomonas putida pada metode bioreaktor dengan penambahan glukosa mampu menghilangkan bau hingga $95.2 \%$.

\subsubsection{Karakterisasi Morfologi dan Biokimia Bakteri Uji}

Berdasarkan determinasi koloni bakteri, diketahui masing-masing isolat bakteri terpilih memiliki kesamaan karakter morfologi koloni yakni, putih, permukaan licin, margin entire, dan elevasi cembung. Perbedaan morfologi untuk setiap bakteri ditunjukkan pada bentuk sel dan pembentukan zona bening. Sedangkan untuk biokimia ditunjukkan dengan adanya pigmentasi media di sekitar koloni (Tabel 4). Isolat uji diduga merupakan jenis bakteri yang berbeda. Hal tersebut diduga dari media selektif yang digunakan dimana media Winogradsky fase I pada isolat WiK 15 dari kotoran ayam dan WiGu 11 dari guano merupakan media selektif untuk bakteri Nitrosomonas (Odokuma dan Akponah 2008), sedangkan media ThioBacillus pada isolat TK 7 dari kotoran ayam merupakan media selektif untuk bakteri ThioBacillus, dimana di sekitar koloni terbentuk zona bening. Menurut Breed et al. (1957) bakteri ThioBacillus merupakan bakteri gram negatif, bentuk koloni bulat dan kecil (diameter 1-2 mm), pertumbuhan lambat. Isolat bakteri $\mathrm{CGu} 7$ dari guano yang diisolasi menggunakan media selektif centrimade untuk bakteri Pseudomonas. CGU 7 diduga merupakan bakteri Pseudomonas putida karena tidak menghasilkan pigmen. Sedangkan isolat $\mathrm{MaGa} 5$ dari tanah gambut perlu dilakukan identifikasi lanjutan karena media yang digunakan merupakan media martin agar yang merupakan media umum.

\section{Simpulan dan Saran}

\subsection{Simpulan}

Lima isolat uji yang potensial non fitopatogen dan non patogen mamalia dipilih berdasarkan kemampuan menurunkan bau serta tampilan permukaan Ekskreta ayam dari uji organoleptik. Berdasarkan pengukuran $\mathrm{NH}_{3}$ isolat $\mathrm{CGu} 7$ menunjukkan kemampuan menekan produksi $\mathrm{NH}_{3}$. Penurunan produksi $\mathrm{NH}_{3}$ oleh isolat $\mathrm{CGu} 7$ sebesar $38.42 \%$. Kelima isolat uji tidak menujukkan kemampuan dalam menurunkan produksi $\mathrm{H}_{2} \mathrm{~S}$ secara signifikan.

\subsection{Saran}

Perlu dilakukan uji kombinasi untuk isolat bakteri WiGu 11 dan CGu 7 untuk mengetahui kemungkinan kompatibilitas antar isolat bakteri. 


\section{Daftar Pustaka}

Breed, R. S, Murray E.G.D., \& Smith N. R. (1957). Bergey's Manual Of Determinateve Bacteriology. (7 ${ }^{\text {th }}$ ed). Baltimore, USA: William and Wilkins Company.

Chesson, P. (1994). Multispecies competition in variable environments. Theoretical population biology, 45(3), 227-276.

Chung, Y. C., Huang, C., \& Tseng, C. P. (1996). Biodegradation of hydrogen sulfide by a laboratory scale immobilized Pseudomonas putida CH11 biofilter. Biotechnology Progress, 12(6), 773-778.

Chung, Y. C., Liu, C. H., \& Huang, C. (2001). Feasibility of fluidized-bed bioreactor for remediating waste gas containing $\mathrm{H}_{2} \mathrm{~S}$ or $\mathrm{NH}_{3}$. Journal of Environmental Science and Health, Part A, 36(4), 509520.

Defoer, N., \& Van Langenhove, H. (2002). Odour emissions during yard waste composting: Effect of turning frequency. In Microbiology of Composting. Berlin, Germany: Springer.

Hidayatun, R. (2007). Produksi ammonia dan hidrogen sulfida Ekskreta ayam broiler yang diberi tepung kemangi (Ocimum basilicum) dalam pakan. Skripsi. Bogor, Indonesia: Program Studi Teknologi Produksi Ternak Fakultas Peternakan, Institut Pertanian Bogor.

Hoerussalam, A. P., \& Khaeruni, A. (2013). Induksi ketahanan tanaman jagung (Zea mays L.) terhadap penyakit bulai melalui seed treatment serta pewarisannya pada generasi S1. Ilmu Pertanian (Agricultural Science), 16(2), 42-59.

Kreis, R. D. (1978). Control of animal production odors: the state-of-the art (Vol. 1). Oklahoma, USA: Environmental Protection Agency, Office of Research and Development.

Lee, M. J., Jin, B. M., \& Hyun, K. Y. (2015). The bio-deodorizing effects of Acidithiobacillus thiooxidans SOB5VT1. International Journal of Innovative Science, Engineering \& Technology, 2(4), 459-464

Muchayani, D. (2013). Efektivitas peggunaan probiotik padat dan cair untuk menurunkan kadar ammonia $\left(\mathrm{NH}_{3}\right)$ dan hidrogen sufida $\left(\mathrm{H}_{2} \mathrm{~S}\right)$ feses sapi potong. Skripsi. Bogor, Indonesia: Departemen Ilmu Nutrisi dan Teknologi Pakan Fakultas Peternakan, Institut Pertanian Bogor.

Nowak, A., Matusiak, K., Borowski, S., Bakuła, T., Opaliński, S., Kołacz, R., \& Gutarowska, B. (2016). Cytotoxicity of odorous compounds from poultry manure. International journal of environmental research and public health, 13(11), 1046.

Odokuma, L. O., \& Akponah, E. (2008). Response of Nitrosomonas, Nitrobacter and Escherichia coli to drilling fluids. Journal of Cell and Animal Biology, 2(2), 043-054.

Palgunadi, N. W. L., Sudarwanto, M., Arka, I. B., \& Pribadi, E. S. (1999). Penambahan mikroba pengurai limbah pada manur untuk menurunkan kadar gas ammonia dan hidrogen sulfide di peternakan babi di Bali. Media Veteriner, 6(1), 15-18.

Patiyandela, R. (2013). Kadar $\mathrm{NH}_{3}$ dan $\mathrm{CH} 4$ serta $\mathrm{CO} 2$ dari peternakan broiler pada kondisi lingkungan dan manajemen peternakan yang berbeda di kabupaten Bogor. Skripsi. Bogor, Indonesia: Departemen Ilmu Produksi dan Teknologi Peternakan Fakultas Peternakan, Institut Pertanian Bogor.

Prasetyanto, N. (2011). Kadar $\mathrm{H}_{2} \mathrm{~S}$, NO2, dan debu pada peternakan ayam broiler dengan kondisi lingkungan yang berbeda di kabupaten Bogor, Jawa Barat. Skripsi. Bogor, Indonesia: Departemen Ilmu Produksi dan Teknologi Peternakan Fakultas Peternakan, Institut Pertanian Bogor.

Rahman, S., DeSutter, T., \& Zhang, Q. (2011). Efficacy of a microbial additive in reducing odor, ammonia, and hydrogen sulfide emissions from farrowing-gestation swine operation. Agricultural Engineering International: Center for Interdisciplinary Geriatric Research Journal, 13(3), 1-14.

Rahman, S., \& Borhan, M. S. (2012). Typical odor mitigation technologies for swine production facilities: A review. Journal Civil Environmental Engineering, 2(4), 1-11. 
Scanes, C. G., Brant, G., \& Ensminger, M. E. (2004). Poultry Science. New Jersey, USA: Pearson Prentice Hall.

Syafrizal, \& Dianursanti. (2011). Pemanfaatan bakteri ThioBacillus thioparus untuk mereduksi kandungan sulfur dalam gas. Lembaran Publikasi Lemigas, 45(1), 65-69

Takagi, T., Tanaka, M., Kamori, H., \& Aritome, K. (1996). Biological Deodorizing Technology. Nippon steel technical report, (70), 15-21.

Wiliams, C. M., Barker, J. C., \& Sims, J. T. (1999). Management and utilization of poultry wastes. In Reviews of environmental contamination and toxicology 162, 105-157. 